\title{
Exploring Priority Problems of the Forest Dependent Poor in Nepal
}

\author{
Harisharan Luintel and Basundhara Bhattarai \\ ForestAction Nepal \\ Email: hl@forestaction.wlink.com.np
}

\begin{abstract}
This paper deals with the priority problems and their underlying causes of the forest and tree dependent poor - resource-poor farmers, landless, small artisan and urban/peri-urban poor - in Nepal, from their own and support agencies' perspectives. The paper is based on a survey conducted in seven districts of Nepal wherein 79 poor people and 65 staff members of support institutions were interviewed. The authors have identified the priority of the identified problems according to the frequency of their reference by the poor. These issues are discussed in seven categories, ranging from daily food insecurity to entrepreneurship development. The results demonstrate that the forestdependent poor have diverse and complex livelihood related problems, which are frequently, but may not directly and exclusively, linked to forestry, per se. As such there is a need for a more continuous holistic and political approach encompassing not only economic but also cultural and social aspects for poverty reduction, in contrast with the existing technical, sectoral and linear approaches.
\end{abstract}

Key words: forest and tree-dependent poor, priority problems, policy, Nepal

\section{INTRODUCTION}

This article is based on the survey entitled "The Priority Problems of the Forest and Tree Dependant Poor in Nepal", which was funded by the Forestry Research Programme (FRP) of the Department for International Development (DFID) of the UK and conducted by ForestAction, Nepal. The survey has documented the prioritized problems and their underlying causes of the forest-dependent poor, particularly small farmers ${ }^{1}$; landless ${ }^{2}$; small artisans (traders and entrepreneurs) ${ }^{3}$; and urban/peri-urban poor 4 (Paudel et al., 2003). The priority problems have been identified according to the perceptions of the poor themselves, as well as those of support institutions that seek to reduce poverty, such as government agencies, non-government organizations, bilateral forestry projects, research institutions and private sectors. All of the problems presented here may appear to be the problems of the general population and the poor in particular, who might not be directly dependent upon the forest, but they may have direct or indirect links to these resources. It is expected that the results of the survey can provide support to the development of meaningful and targeted actions, both through further research and through development actions, so as to contribute to the increased understanding of the links between pro-poor forest management policies and practices. Moreover, this is expected to contribute to and reinforce pro-poor policy formulation and implementation processes.

1 Small farmers constitute the majority of poor farmers' groups in Nepal, described as subsistenceoriented farmers, small landholders and low cash income groups.

2 The livelihoods of the landless are primarily based on agricultural wage labour. These groups are either from the traditional occupational castes, are transitional migrants to the Terai and urban areas or are the people displaced as a result of natural calamities.

3 Artisans herein primarily constitute the traditional occupational castes as well as the small traders/entrepreneurs whose livelihood is primarily based on cash income.

4 The urban and peri-urban poor are viewed as poor families residing in the urban/peri-urban area with very small or no land holdings primarily with daily wage-based livelihoods and exposure to pollution. 


\section{BACKGROUND TO THE SITUATION}

Nepal is characterized as a mountainous country with rugged topography; having a heterogeneous (and exploitative) society in terms of caste, class, gender, ethnicity, resource access and power relations; and with a subsistence-oriented agricultural economy. Khadka (1991) argued that agricultural production of the country accounts for 59 percent of the Gross National Product and employs 90 percent of the economically active population. However, the agriculture sector is virtually stagnant, leading towards critical food shortages. According to the National Planning Commission, a person having a per capita annual income of less than NRs. 6,100 (about US\$87) is considered to be below the poverty line. The Nepal Living Standards Survey 2003/04 shows that about 95 percent of rural Nepalese people are living below this poverty line (CBS, 2004). Likewise, UNDP (2002) reports that despite the per capita annual income growing by an average rate of $2.7 \%$ during the 1990s, the incidence of poverty has remained high, largely because of disparities in the ownership of resources. For instance, land resource distribution is so skewed that the richest nine percent of landowners own 47 percent of the nation's farmland, whereas the poorest 67 percent own only 17 percent (Ghimire, 1992). Moreover, the World Bank has described Nepal as one of the least developed countries in the world (IBRD, 1991).

Due to the complex nature of poverty, its reduction is a daunting task for which there are no quick and easy solutions. Understanding the key problems of the poor is crucial in devising poverty reduction strategies and programmes, because of which the government and development institutions have long been criticized for their top-down interventions. More often, 'experts' do poverty analysis and devise strategies to reduce it. Though they have good knowledge to analyse poverty through diverse theoretical and conceptual perspectives, their efforts have been contributing more to visualize poverty from different dimensions and create common understanding on it among experts, support agencies and "professionals". There are limited efforts made to understand the ways in which the poor perceive their own problems. Moreover, there is limited space for the poor to be involved in the poverty reduction policy and planning processes. A result of their lack of inclusion in participatory policy and planning processes, there is less chance to prepare effective and acceptable policies and programmes. Hence, limited impact has been observed on the livelihoods of the poor. Even though billions of dollars have been spent over the course of the past forty years, planned development efforts in Nepal have failed to significantly reduce the levels of poverty (Pandey, 1999).

Despite the results of past development efforts, there are some recent holistic as well as sectoral initiatives coming from policy and/or programme levels that have emphasized poor-focused activities. The attempt to formulate a focused poverty alleviation programme as a long-term perspective plan was initiated with the Seventh Five-year Plan (1985-90). However, initially, the attention was given only to the economic aspects due to a lack of appreciation for the other dimensions of poverty. As the understanding of poverty issues has gradually widened, different dimensions of poverty, such as social, cultural, and human aspects, have been recognized and given due consideration in planning. The current Tenth Five-year Plan (2002-2007) has given more attention to reduce poverty through these different dimensions. Moreover, the government has prepared a Poverty Reduction Strategy Paper (PRSP) in line with the Millennium Development Goal (MDG) of halving poverty by 2015. MDG has a focus on reducing the population in extreme poverty by $50 \%$, defined as those people whose income is less than one dollar per day (http://www.developmentgoals.org). In addition to this, the government-prepared PRSP aims to reduce poverty from 38 percent to 30 percent within the plan period of 2002- 2007 by bringing positive changes on the following four pillars of development:

(a) Broad-based economic growth;

(b) Rural infrastructure initiatives and social priority sectors;

(c) Targeted interventions, including poverty alleviation funds, and

(d) Decentralization and social mobilization initiatives. 
The PRSP also recognizes the inter-linkages between poverty reduction and good governance, stating the government's commitment to improve governance by focusing on such components as civil service reform, decentralization and the increased role of non-government sectors in service provisioning (UNDP, 2002). In addition, a number of sectoral master plans and/or programmes with explicit goals for poverty reduction have been prepared and implemented with support from donors, including Community Forestry (CF), Leasehold Forestry, local governance programmes, community health, microenterprise development, the Small and Cottage Industries Promotion Programme, rural banking, savings and credits schemes, cooperatives, and agriculture and livestock development. Different organizations, such as government agencies, I/NGOs, federations and alliances, user groups, bilateral projects, the private sector, cooperatives and the local government bodies, have been involving themselves in planning and implementing these

\section{METHODOLOGY}

The survey was conducted in seven districts of Nepal, covering different ecological and developmental regions with diverse social and ethnic variations. The districts covered in the survey were Siraha, Dolakha, Kabhrepalanchok, Chitwan, Nawalparasi, Banke and Kailali (Map 1). The survey was conducted between April and October 2002, incorporating the views of 79 poor people and 65 staff members of support institutions, including government agencies, non-government organizations, bilateral forestry projects, research institutions and the private sector. The study is based on a participatory survey methodology, capturing a broad cross-section of informants' perceptions and views through direct personal interviews. An attempt was made to allow the interviewees to reflect on their realities through an interactive interview process. In addition to the field survey, relevant literatures, particularly the national policy strategy and action plans, were also reviewed. programmes through a wide range of activities: advocacy and empowerment, service delivery, infrastructure development, income generation activities, technology transfer, material supply, financial support, research and education, social change and resource management. The forestry sector, being one of the important sources of livelihoods for people, particularly the poor, has been playing a crucial role through the development and implementation of propoor policies and programmes. As part of addressing the issues of poverty and contributing to the achievement of the MDG, the Forestry Sector Coordination Committee has identified three major issues, frequently referred to as second-generation issues, to be addressed in $\mathrm{CF}$, including good governance, livelihood improvement and sustainable forest management (Kanel, 2004). In addition, some NGOs and users' federations are heavily involved in addressing these issues at the national level by facilitating discourses and at local levels by developing participatory action and learning processes (Luintel, 2006).

Map 1. Study districts

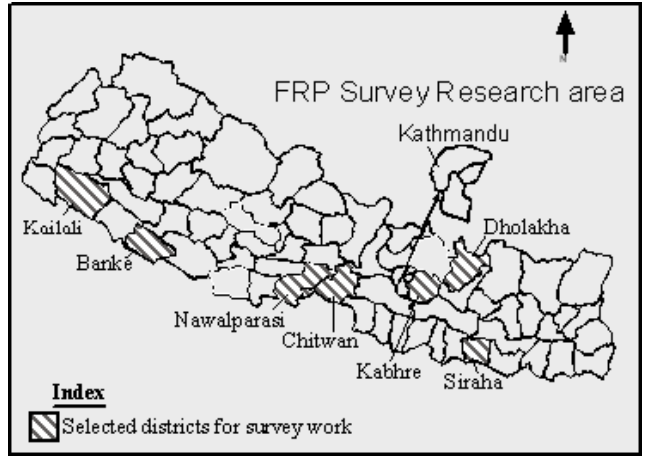

The survey has identified the priority problems of the individual respondents and their underlying causes in the form of problem trees. By compiling all of the problems mentioned by the respondents, a comprehensive list of problems was prepared and the frequency of particular problems cited by the focus groups was counted to identify the most commonly prioritized problems. Moreover, the causes of these problems are also explored and documented. 


\section{KEY PRIORITY PROBLEMS}

From the survey, sixteen problems have been identified as the priority problems of the forest-dependant poor in Nepal. However, we have grouped them into seven relevant groups for discussion. These problems range from day-to-day food security to shrinking markets for their products. The problems seem to have been created as a result of a wide range of factors: from contextual cultural causes such as caste, gender, and class-based discrimination to globalization, technological advancement and national policies and programmes. Almost all of the problems appear to be inter-related and are not independent of each other. Any single problem may cause a rise in others, perpetuating the vicious cycle of the poverty. Discussions of these prioritized problems, primarily on the basis of the survey and supplemented by literature, are given below.

\section{Lack of Favourable Policies and Support Services}

Though there are various sectoral policies addressing the issues of poverty, these are not adequately defined to provide resource access and services delivery to the poor. This is partly due to the following of a generalist or arbitrary approach to policy, without considering the diverse peculiarities of different farmer categories, as well as the biophysical contexts and socio-cultural systems and their analysis and consideration in preparing policies. This view is supported by a study carried out by Blaikie and Sadeque (2000). Moreover, there is confusion among different sectoral policies, leading to their failure to guarantee the rights of the poor to resources and services. For instance the 'Dual Land Tenure System $^{5}$, has emerged as a result of conflicting, confusing and complex land policies in Nepal. Such conflicting policies have not only adversely affected the productivity of the land, but have also alienated poor to entitle land.

A complex and lengthy land registration process is often a barrier to the poor in establishing land ownership. Narayan et al.

\footnotetext{
5 There is the prevailing system of landowner and tenant, in which both have shared rights over the land and the production.
}

(2000) pointed out that, due to the weak organization of the poor and their inability to demand accountability from the elected or appointed leaders, in addition to discriminatory social relations, the landless and occupational castes, particularly the dalits, have rarely been able to get land titles. Thus, the poor have been forced to live either as bonded labourers (known as Kamaiyas in the Terai districts), serving landlords for generations, or they depend upon common property resources or on traditional occupations, such as sewing or cobbling, for their livelihoods. A government commission identified approximately 17,000 bonded labour families living in five western Terai districts (Robertson and Mishra, 1997). In addition, persisting resource management conflicts among local governments, resource user groups and the national government have further hit the poor, raising transaction costs. Due to the lack of a policy to safeguard the poor against elite control over resource management decisions, community forests and irrigation facilities are being used inequitably, often leading to additional costs to poor and marginalized (Neupane, 2003; Malla, 2001 and Malla et al., 2003).

Moreover, the implementation of wage policies is found to be weak, due to a lack of an effective implementing and monitoring system. As a result, there are differential and discriminatory wage rates within the marketplace, negatively affecting women and marginalized populations, in particular. Further, there is a lack of policy incentives or simple and transparent procedures for the promotion of cottage industries in the rural areas, particularly for those that are forest- or agriculture-based. This has hindered the employment opportunities of the poor living in rural areas. Besides, trade policies favour the development of modern household articles and agricultural implements, which are generally produced by multi-national companies, thus losing the traditional knowledge and market access of the poor and occupational castes. For example, the production of plastic ropes has severely affected traditional fibre enterprises.

Since the poor have fewer alternatives to their livelihoods and less opportunity to lead a dignified life, they are always in need of special services from the government and 
other support agencies (ActionAid, 2004). Nonetheless, there are already some initiatives in pro-poor programme design such as in Leasehold Forestry and within the $\mathrm{CF}$ framework but the effectiveness of these designs have yet to be demonstrated. As the distance from the capital city or the district headquarters increases, where greater numbers of the poor live, the ability of service providers to provide sufficient services becomes inadequate, inefficient and ineffective. This situation is accelerated due to the prevailing social unrest. Technical services and input-delivery mechanisms are weak (Blaikie and Sadeque, 2000), partly due to the inherent limitations of bureaucracy to reach poor people, and partly due to the limited skills and abilities of programme staff to deal with the emerging complexities in poverty reduction. Many institutions working to support the poor lack the necessary knowledge, experience, skills and programmes to manage particular resources and run profit-making ventures, an approach that can help the poor to break the vicious cycle of poverty. One of the respondents from Sati Karnali said that the Sati Karnali Community Forest User Group (CFUG) of Kailali district has not received the trainings or other technical supports that they had requested to improve the management of the cane forest and the processing and marketing of its products. He further added that if this group would receive such support, a number of poor would become employed through the business.

In the $\mathrm{CF}$ context, field staff is largely unable to provide relevant and adequate technical services to farmers (Springate-Baginski et al., 2000). Evidence of this is found in Dhital et al., (2002), in which it is reported that $78 \%$ of the community forest operational plans are waiting for a resource inventory and subsequent renewal of the plan. In addition, basic welfare services such as health facilities, schools, drinking water supply and road networks are also lacking in the areas where poor reside. This is due in part to the areas' geographical isolation, regional discrimination of the state and the low political will of the political actors. Some of the good policies also suffer from severe distortions in implementation due to nepotism, bribes and bureaucratic hassles, such as is found in land registration, property transfer processes, and non-timber forest product (NTFP) transportation and trade. These types of inefficiencies, ineffectiveness and incapacity adversely affect the poor more than other sections of the population.

\section{Shrinking Market for the Poor's Products and Services}

All of the poor are suffering from a lack of market access, marketing infrastructure and information for their products (forest- and agriculture-based) and services, predominantly labour. Small-scale producers and labourers are forced to sell their products and the services at low prices because of their low bargaining power. This power is low as their products and services are usually of limited quantity, are perceived as being of low quality as compared to modern industrial products, are often supplied erratically and are often perishable in nature. There is a lack of cooperatives and organized sectors for the marketing of their products and services, a result of which is that the poor are becoming more vulnerable to exploitation. Generally, the poor incur high production costs in producing goods and services due to manual and small quantity production processes and their dependency on traditional skills and primitive technologies. There is no policy provision to subsidize their production cost. Poor and small artisans have little knowledge of the changing market conditions, which limits their scope for business expansion. Moreover, they have to compete with the larger, more efficient, effective and influential industrial sector. As a result, small-scale artisans are being left behind and are ultimately losing their business. For example, traditional cobblers' businesses have been replaced by the modern shoe industry and traditional bamboo baskets have largely been replaced by plastic baskets, particularly in the urban and peri-urban areas. Similarly, the unrestricted cross-border migration of Indian workers further reduces the market opportunities for local artisans. Indian barbers have largely replaced the traditional barbers of Nepal. Moreover, the existing exploitative social system does not normally allow for the occupational caste poor artisans to bargain for a better price, particularly in the rural areas. They are paid 
a fixed quantity of grain, either seasonally or annually, regardless of the volume of the work that they have done. Likewise, many small-scale milk producers often have to bear the cost of forced milk holidays and centrally dictated milk prices. NTFP collectors, for example, complained about serious problems in getting instant cash payments for their products. As they are often compelled to ask for advances, their position for negotiating prices becomes weaker (Luintel, 2002 and Ojha, 2001).

\section{Restriction of Access to Natural Resources and Financial Capitals}

Since most of the resource-poor farmers are pushed to the marginal rain-fed land where the risk of natural calamities (e.g. floods and landslides) is higher, the productivity of the land has been reduced drastically. Moreover, frequent livestock and crop diseases are also reasons for low agricultural productivity. To increase productivity, many resource-poor farmers lack access to agriculture inputs, mainly due to their unavailability and high cost. The traders create an artificial shortage of these inputs, such as chemical fertilizers and improved seed, during the peak season of demand to raise the price. In addition, low quality substitute products are supplied at such times and poor farmers are further cheated.

In addition, the poor are further marginalized in equitably receiving economic and political benefits from the managing bodies of common property management schemes, such as $\mathrm{CF}$ and irrigation. Due to continued practices of social, economic, cultural, political, and geographical exclusion in society, the poor and marginalized are prevented from accessing forest resources, despite the existence of policy provisions for their right to access these resources. Many poor communities are still waiting for forests to be handed over to them, particularly in the high hills and in the Terai. There are a number of cases that have demonstrated that the poor are receiving less benefit from the forest as compared to other members of the same community. The access of the poor to forest products and decision-making is also highly contested by the higher-class members of the community (Bhattarai and Ojha, 2001; Malla, 2001; Neupane, 2000; Maharjan, 1998). Further, CF is not empowering the most disadvantaged groups, as desired (Lama, 1999; Bhattarai, 1999). The government policy and/or community rules also make no allowance to the special needs of poor and their customary use rights often go unprotected (Ruis, 2001). A study by Springate-Baginski et al., (2000) revealed that two-thirds of 11 CFUGs studied were restrictively ruled by their committee or even unilaterally by their chairmen. These inequities are the result of the existence of ad hoc, top-down and inappropriate decision-making processes in both the communities and in facilitating institutions (Luintel, 2006). Furthermore, the commonly practiced passive or timber-based forest management hinder the access of the poor to the required forest resources, particularly NTFPs. Many small artisans such as potters, craftsmen, basket makers, blacksmiths, coal makers, firewood cutters, etc. are deprived of the raw materials of their livelihood occupations. The collection of raw materials from the forest (e.g. soil, particular species, bamboo and wood) is now mostly banned, either by the community or the government. Moreover, such products are gradually being destroyed due to high population pressures, further pushing the livelihoods of the poor towards vulnerability. Similarly, fisherman living around rivers located near national parks and protected areas are not allowed to fish as they wish in order to generate their livelihoods as the National Park Authority has introduced a restrictive licensing system for fishing.

Improved working environments and physical facilities such as storage, electricity, and hygienic working places are desperately needed by artisans to continue and promote their occupations. To access these facilities demands input of financial capital, virtually impossible for the poor in the formal sector, primarily due to the existence of guarantee- and mortgage-based lending policies, the presence of limited village-based financial institutions, complex and lengthy lending processes, and bribery and nepotism to sanction the loan. However, there are few village based saving credit initiatives facilitated by various local institutions such as CFUGs, cooperatives etc. These are not sufficient to cater the demand of poor and marginalized, as many of them are unable to be the member of such groups. In addition, traditional local 
practices are mostly favourable to the rich and elites only. Thus, poor farmers are often forced to rely on excessively costly loans, having interest rates as high as $60 \%$, from local traditional lenders. Such loans push the poor into deeper levels of poverty in the long run.

\section{Limited Education, Awareness and Skills}

Child labour, child marriage, financial constraints, and caste-, ethnicity- and gender-based discrimination are limiting factors for education opportunities for the poor, in addition to a lack of motivating factors and adequate facilities on the part of the government. Moreover, there is a high dropout rate at primary school among dalits, ethnic minorities, girls and the poor. Nearly $30 \%$ of Nepali children, mostly those from poor households or disadvantaged groups and regions, lack access to basic primary education (UNDP, 2002). Remoteness, geographical isolation, and a lack of infrastructure development and government commitment further aggravate the problem. Higher education and vocational training are not only inaccessible to the poor, but remains beyond their imagination. The government and the private and nongovernmental sectors have also been unable to create a conducive and accessible environment for the formal education of the poor.

Due to a lack of awareness about the rights of the citizens, particularly in relation to social justice and different forms of human rights, the articulation of the interests of the poor in policies and programmes is very limited. Defending the rights of the poor, which are sourced from nature; international conventions; the national constitution; and customary, cultural and social practices, also needs to be carried out by civil society organizations (CSOs), which are generally led by the rich and elite, because of the difficulty in forming an organization by the poor.

Nearly all of the poor have to rely on their skills for their livelihood. However, they lack the skill required to work in alternative trades, such as masonry, carpentry, plumbing and sewing. Most of the artisans lack skills in operating their businesses in innovative ways, which would enable them to produce better quality products, able to compete with industrial products already in the marketplace. Most small farmers do not know how to process their products so as to add value and get higher returns. Accessing modern skills is very difficult for the poor, since they tend to be expensive and not easily available. Thus, most of them rely on traditional skills, these being very contextual in nature but adaptable in coping with local situations. Most of these skills are of a riskaversion type and are used to sustain their livelihood. These skills are not sufficient enough to allow for competition at commercial scales. There are no formal institutions to support training for the upgrading of traditional skills and for the transference of those skills to the next generation. These skills are transmitted informally from generation to generation with high risk of loss. Moreover, many people of the younger generations do not want to continue the traditional occupations because they feel that it is a low social status job that gives low economic return.

Although there are a few vocational training centres, most of them are inaccessible to the poor. Moreover, it has been found that they ignore the need of the poor while developing training curricula and delivering the training. Some of the government development agencies also design training courses and deliver the training in the same way. Thus the adoption rate of the trainings is very low. A baseline survey of USAID showed that the overall training adoption rate regarding forest management and skill development is 3\% in Banke district (pers. comm. with Ishwor Neupane, 2002). The rate falls to nil in Dhading and Bardiya districts for disadvantaged groups and women (ibid). However, the government has not paid sufficient attention towards this issue.

\section{Lack of Food Security}

Throughout most of the hilly region, subsistence farming is the major source of food. However, the productivity of the land in those places is very low, due to a lack of agricultural inputs, the use of primitive technology, occurrences of natural calamities such as landslides and flooding, sharecropping systems, insect/pest attacks and crop diseases. Thus, the production levels have been reduced significantly and 
food insecurity has become a major concern of the local people of that region. Most of the occupational castes such as Kami, Damai Sarki in the hills, and Chamar, Bhand, Mushahar, Dhankar and Badi in the Terai suffer food insecurity. This is also evident in the survey of World Food Programme (WFO, 2000). Some of the landless and resource poor groups, particularly the occupational castes, rely mostly on NTFPs such as fruits, leaves, flowers and tubers for their food. However, the full benefits achieved from NTFPs are yet to be achieved. In addition, large family size and economic dependency on one or two family members also increases the risk of food insecurity. Large family size is a major cause of land fragmentation, higher livelihood costs and intra-household inequity, ultimately leading to chronic poverty.

People have a tendency to have more children in many poor communities because they are considered as additional labour force able to secure food. Culturally, people prefer to have male children and they want to counter the high mortality rate. Similarly, lack of access to reproductive health services further increases the birth rate among poor. Most of the children of the poor work as household helpers in the town, although some take care of the livestock of the village elites. Despite the existence of laws banning child labour, the government has no concrete plan to provide social security, basic education and primary health facilities to children.

\section{Lack of Employment and Income Opportunities}

Since agriculture is mostly subsistenceoriented and seasonal in nature, there is a possibility of partial employment for the local people. Underemployment is a major problem of rural farming communities, with $40-60 \%$ of the adult labour force being underutilized (MEDEP, 2001). Many rural poor are highly dependent on off-farm employment for their livelihoods. Thus, they are forced to move to the towns and Indian cities to tap employment opportunities

\section{DISCUSSION}

Looking at the initiatives and actual practices, there are gaps observed in addressing poverty issues at different dimensions, forms and levels. The lack of
(Ohler, 2000). The recent changes in technology and economic policies at global, national and local levels have reduced the opportunities for labour-intensive employment for local unskilled people. The poor have to rely heavily on market-based employment opportunities for cash income, for which they often lack the necessary skills. Moreover, nepotism, bribery and social discrimination prevent them from getting employment in modern production sectors. Further, women are not allowed to work outside of the household in some communities.

\section{Exploitation and Limited Access to Decision Making}

The poor and landless are more vulnerable to bullying by powerful groups. Most of them are unable to receive citizenship documents and to be listed on voters' lists, due to lack of land entitlement and migration. The occupational caste groups are often considered as low or "untouchables" and are denied access to existing decision-making forums, which apparently leads to their limited access to resources that are under the control of local institutions, such as community forests and primary education. The rich and elite dominate these local institutions, leading to the non-recognition of the voices of members from the occupational castes and the poor (Malla et al., 2002). CFUGs, which are generally considered to be democratic institutions, are not always fair and certain users are discriminated against because of their lowcaste status (Chhetri and Nurse, 1992). CFUG members are predominantly from economically advantaged groups, and disadvantaged groups are often excluded from membership and may loose access to vital resources (Graner, 1996, 1997). In addition, women in most of the communities are exploited, not only socially, but also economically, irrespective of geographical region and caste. They suffer from household violence as well as social, economic and political discrimination.

consultation with the poor in policy-making processes, the sectoral approach to development, an absence of exclusively poorfocused development agencies, etc., create 
gaps in addressing the problems of the poor. Furthermore, limited space for civil society organizations (CSOs) and the private sector are provided in the policy-making and implementation processes. Public welfare services such as communication, roads, education, health, and drinking water facilities in rural areas are provided predominantly by the government alone, which are not as effective, efficient or implemented as required. A high degree of discretionary power in decisions regarding such services remains with the central bureaucracy, which is generally unfamiliar with the local requirements. As a result, several issues have been raised, including the high prices for services, delays in service delivery, and limited responsiveness to demands. There is limited appreciation of politically-oriented services, such as advocacy campaigns and peaceful demonstrations in changing exploitative power relations among different sections of the society as well as between the government bureaucracy and the people. Most of the development agencies are unable to adequately identify the poor and to reach them in the true sense, as they are not sensitized to provide services exclusively to the poor. Moreover, the communities' institutions, in which government bureaucracy and donors also rely upon to deliver services to the poor, are dominated by the rich and elites and do not truly represent the agendas of the poor. Local government, responsible for local development, is also captured by local elites who want to maintain the status quo. Thus, there are only limited programmes being put in place to address the different dimensions of the livelihood assets of the poor in the sectoral development programmes.

There is an acute shortage of policies and programmes articulating and protecting the interests of the poor, enabling them to access public services and providing them with special services. There are limited institutions that are committed and competent enough to work specially for the poor, either exclusively or inclusively. Though there are some initiatives to promote community-based poor support programmes in the forestry sector, these efforts still need to be consolidated and linked with broader socio-cultural, political and policy processes. Moreover, these developmental efforts seem to be a "quick fix" and less sustainable, as these do not adequately contribute to the root causes of poverty.

Similarly, poverty issues have not become the agenda of social and cultural practices in our society until the recent past. Rather, socio-cultural values, norms and practices have become instruments for the rich and elite to further exploit the poor. Despite the lack of adequate policies and appropriate programmes, some of the critical factors that pose challenges to institutions working for the poor might be the small scale of the service demand per unit of geographic area, the shortage of supplies for services and materials, inefficient service delivery mechanisms, inadequate private service providers, and geographical isolation of the impoverished communities in need.

We see that the poor have limited access to all the livelihood capitals that include financial, physical, social, natural and human capitals. The livelihood dependency of the poor on the natural capital i.e., forest has been higher from the past. The forestry sector is an important employer and income generator, especially in the rural areas (Dahal et al., 1999). However, the potential of the forestry sector in poverty reduction has not been fully recognized and this is one of the reasons why this sector has received, on average, only 4.6 percent of total government expenditures (FAO, 1997). Though forestry is a more decentralized sector than others, having shifted decisionmaking authority to local users groups, it has not addressed the equity concerns at large and the poverty reduction objective has not been sufficiently addressed. The access to forest and forest products for them is skewed due to not handing over the national forests that are potential to handover to the local communities by the government and also elite domination in decision-making and benefit sharing within the participatory forestry processes that have already established. Despite the exclusive dealings of the Ministry of Forest and Soil Conservation with the problems of the poor through the Leasehold Forestry Programme, the actual impact is still being debated (Thoms et al., 2003; Bhattarai et al., 2005). However, there are quite a few examples that the $\mathrm{CF}$ have been able to support poor to increase their access not only to the forest resources (natural capital) but also to other 
livelihood capitals such as awareness raising (human capital), decision-making (social capital), fund mobilizing for poverty reduction (financial capital), and developing physical facilities which is accessible to the poor (physical capital). Moreover, CF has been providing spaces to discuss the social, cultural and political challenges that the poor and marginalized are facing. The policy provisions and communities' practices of democratic decision-making processes and forest management contributions are gradually helping to address equity issues within the CFUGs. Increasingly, the voices of poor and marginalized are being heard at local levels and the issue of equity in cost and benefit sharing is in the discourse at the national level (Kanel, 2002).

Though poor realized that there are opportunities of using forestry in poverty reduction, they have rated the problems related to low level of access to natural resource i.e., common property as lower then that of pro-poor policy, special and exclusive support services, market for their products and services which are directly concerned with the entitlement of private property. This indicates that dealing with forest dependent poor through only increasing access to the forest might not help much unless initiatives are also focussed on resolving the problems other than forestry particularly related to the creation and development of private property regime for them.

Policy makers generally look at the strategy of poverty reduction from a unidirectional approach and linear model. For example, landless families are seen only from the dimension of landlessness, and the government has tried to some degree to provide them with pieces of land, usually in the national forest areas. However, there might be many ways, which are not explored, to support the poor to make them able to tackle their problems as their priority problems are of different nature and types. Due to government favouring sectoral

\section{CONCLUSION}

The results of the survey show that poverty is rampant in Nepalese society, being manifested in multi-dimensional forms and different scales, levels and intensities. Poverty has been further ingrained in approaches to development and poverty reduction programmes, there is limited space for implementing agencies to be flexible enough to accommodate the dynamic and contextual interests of the poor. The poor need both technical (i.e. skills and business inputs) and political (i.e. awareness, empowerment, peaceful movements) services to capacitate them and create favourable power relations among various actors in society at different levels. For all such services, they are not in a position to pay the entire cost; neither can the market solely provide these services without charge. Thus, public subsidies through government or the non-profit sector is a must. At the same time, technical services for which the poor can pay may also be promoted. Proper and adequate policy and institutional support to promote such services are still limited and thus the sustainability of these few good initiatives are in question. Moreover, the scaling-up of effective and improved innovations is inadequate and limited both temporally and spatially.

Any changes in resource management, entitlement and benefit distribution systems directly affect the poor, as they have limited access to other options to fulfil their livelihood needs. Thus, considering the principles of social justice, they need to be consulted and involved in the policy, decision-making and programme implementation processes related to the management of those resources. However, specific poverty reduction programmes have also been criticised as being "top down" and non-participatory, as these programmes are developed externally, the programmes being designed and implemented by outsiders, thus giving limited space to the poor to spell out their concerns. Given the existence of such policies for poverty reduction, limited impacts on the livelihoods of the poor have been observed, raising questions as to whether the actual problems of poor are being addressed.
Nepalese society not only on the basis of, but also manifested in, the forms of historically- and culturally-constructed unequal power relations, defined by caste, class, gender and regional settlement. 
Poverty is not recognized as a simple and static phenomenon, but rather as a deeprooted, complex and dynamic one, making approaches for its reduction more ambiguous, contextual, subjective and relative. However in most cases, poverty has been perceived in the forms of those being in settings of low income and capacity, high risk and insecurity, deficiency in livelihood assets, social exclusion, and lack of education, among others. The understanding and approach towards reducing poverty continues to be contested while being applied in the development field.

The forest and tree dependent poor and their supporters perceive that the limited policy and programmes on the part of government and non-profit sectors as the most crucial point which need immediate action, through the creation of policy provisions and development programming to exclusively favour the poor. Three different types of actions that the poor expect are:

- formulation of new policies wherein the problems of the poor are directly addressed,

- changes in current policies that are not positively addressing the problems of the poor, but rather are creating obstacles, and

- ensuring that the implementation of the poor-favouring policy is conducted correctly.

Though government has been systematically addressing poverty issues, there continue to be many gaps observed in different dimensions, forms and levels. The lack of truly participatory pro-poor policy-making processes creates an environment for less effective policy and programme development that are, in turn, less acceptable to the poor. Similarly, limited spaces for CSOs and the private sector within the policy-making and implementation processes have further limited their contribution to the poor. Existing socio-cultural practices on economic transactions continue to be in favour of the rich and elite, particularly within the rural areas of Nepal. Moreover, the poor have been restricted from getting employment opportunities as a result of various barriers. Markets for the products and services of the poor have also been shrinking. These all result in the reinforcement of the cycle of poverty.

In contrast to the existing technical, sectoral and linear approaches, which focus more on economic aspects of poverty, there is a need for a continuous, holistic and political approach, encompassing cultural and social aspects for poverty reduction. To bring together different types of expertise and resources to fight against poverty, there is also an increasing need to strengthen and expand the roles played by CSOs and the private sector. A shift in this direction necessitates reformation in governance, including a redefinition of the roles of state authorities, civil society and markets. However, there continues to be limited recognition of the potential contribution of civil society and the private sector in reducing poverty in the true sense.

\section{ACKNOWLEDGEMENT}

Authors would like to acknowledge Forestry Research Programme of Department for International Development, the UK for the financial support for the survey, the survey respondents from poor communities and support institutions for their information and insights and the reviewers for providing a comprehensive and very important feedback to complete the paper.

\section{REFERENCES}

ActionAid, Nepal. 2004. Listening to the People Living in Poverty in Nepal. Analysis of Life History Cases: Volume II. Bangalore: Books for Change.

Bhattarai, B. \& Ojha, $\mathbf{H}$ and Humagain, $\mathbf{Y}$. 2005. Is Leasehold Forestry Really a ProPoor Innovation? Evidences from Kabre
District, Nepal. Forest and Livelihood, 4(2): 17-30.

Bhattarai, B. \& Ojha, H. 2001. Distributional Impact of Community Forestry: Who is Benefiting from Nepal's Community Forests? ForestAction Research Series 00/01. Kathmandu: ForestAction Nepal. 
Bhattarai, B. 1999. Distributional Impact of Community Forestry: Cost-Benefit Analysis of Forest Management for Various Income Groups of Forest Users. Pokhara, Nepal: Institute of Forestry, Tribhuwan University.

Blaikie, P. \& Sadeque, S. 2000. Policy in High Places: Environment and Development in the Himalayan Region. Kathmandu, ICIMOD.

CBS. 2004. Nepal Living Standard Survey 2003-2004: Volume II. Kathmandu, Central Bureau of Statistics, National Planning Commission Secretariat, His Majesty's Government.

Chhetri, R.B. \& Nurse, M.C. 1992. Equity in User Group Forestry: Implementation of Community Forestry in Central Nepal. Discussion Paper 1-92. Kathmandu: NepalAustralia Community Forestry Project.

Dahal, M.K.; Acharya, K.P.; Dahal, D.R.; Bhattachan, K.B. \& Nepal, M.K. 1999. Development Challenges for Nepal. Kathmandu, Nepal: Foundation for Advanced Studies (NEFAS) and Finnish International Development Agency (FINNIDA).

Dhital, N.; Paudel, K.P. \& Ojha, H. 2002. Inventory of Community Forests in Nepal: Problems and Opportunities: A Brief Report Summarizing the Findings of Telephone Survey and Field Interviews in 40 Districts. Kathmandu: ForestAction and Livelihood and Forest Programme.

FAO. 1997. Asia-Pacific Forestry Sector Outlook Study. Working Paper No APFSOS/WP/32. Country Report Nepal. Kathmandu: FAO.

Ghimire, K B. 1992. Forest or Farm? The Politics of Poverty and Land Hunger in Nepal. Delhi: Oxford University Press.

Graner, E. 1996. User Group Forestry - Poor Policy for Poor People? Nepal's Forest Legislation from a Political Ecology Perspective. Germany: Freiburg University.

Graner, E. 1997. Kami Today: Forest and Livelihood Security. Nepalese Studies, 24(2):217-231.

HMGN. 2002. Tenth Five-year Plan. Kathmandu: National Planning Commission. http://www.developmentgoals.org. Viewed on $02 / 02 / 2006$.
IBRD. 1991. Poverty and Incomes. Washington DC: The World Bank.

Kanel, B. 2002. Leasehold Forest for Communities below the Poverty Line. Kathmandu: Department of Forest.

Kane1, K. R. 2004. Twenty Five Years of Community Forestry: Contribution to Millennium Development Goals. In Twenty Five Years of Community Forestry: Proceedings of the Fourth National Workshop on Community Forestry, (pp. 4-18). Kathmandu: Community Forestry Division, Department of Forest.

Khadka, N. 1991. Foreign Aid, Poverty and Stagnation in Nepal. Kathmandu: Ratna Pustak Bhandar.

Lama, A. 1999. Changing Roles of Women in Forest Resource Management: The Case of Community Forestry in Nepal. Canberra, Australia: School of Resource and Environmental Management, Department of Forestry, The Australian National University.

Luinte1, H. 2002. Issues and Options of Sustainable Management of Himalayan Medicinal Herbs. Forest and Livelihood, 2(1): 53-55.

Luintel, H. 2006. Do Civil Society Organizations Promote Equity in Community Forestry? A Reflection from Nepal's Experiences. In S. Mahanty, J. Fox, M. Nurse, P. Stephen and L. Mclees (Eds.), Hanging on the Balance: Equity in Community-Based Natural Resource Management in Asia (pp. 122-142). Bangkok: RECOFTC and East-West Centre.

Maharjan, M. 1998. The Flow and Distribution of Costs and Benefits in the Chuliban Community Forest, Dhankuta, Nepal. Rural Development Forestry Network 23e: 1-12.

Malla, Y B. 2001. Changing Policies and the Persistence of Patron Client Relation in Nepal. Environmental History, 8(2): 287-307.

Malla, Y. B.; Barnes, R.; Paudel, K.; Lawrence, A.; Ojha, H. \& Green, K. 2002. Common Property Forest Resource Management in Nepal: Developing Monitoring Systems for Use at the Local Level. Kathmandu: ForestAction, Nepal and IRDD, Reading University, UK. 
Malla, Y.B.; Neupane, H.R. \& Branney, P. 2003. Why Aren't Poor People Benefiting More from Community Forestry? Forest and Livelihoods, 3(1): 78-90.

MEDEP. 2001. Micro-Enterprises for Sustainable Livelihoods, Annual Report 2000. Kathmandu: UNDP.

Narayan, D.; Chambers, R.; Shah, M.K. \& Petesch, P. 2000. Voices of the Poor, Crying Out for Change. Washington DC: World Bank.

Neupane, H.R. 2000. Factors that Influence Poorer Households' Access to Forest Products from Community Forests: An Analysis of Decision-making and Benefit Sharing Processes. UK, The Reading University.

Neupane, H. 2003. Contested Impact of Community Forestry in Equity: Some Evidences from Nepal. Forest and Livelihood, 2(2): 55-61.

Ohler, F.M.J. 2000. The Impact of Leasehold Forestry on Livelihoods and Environment. Kathmandu: Food and Agriculture Organization of the United Nations.

Ojha, H.R. 2001. Commercial Use of NonTimber Forest Products - Can the Poor Really Get Benefits? Forest and Livelihood, 1(1): 19-21.

Pandey, D.R. 1999. Nepal's Failed Development: Reflection on the Mission and
Maladies. Kathmandu, Nepal South Asia Centre.

Paudel, K.P,; Luintel, H.; Bhattarai, B.; Ojha, H. \& Hanna, J. 2003. Priority Problems of the Forest and Tree-Dependent Poor in Nepal. Kathmandu: ForestAction, Nepal.

Robertson, A \& Mishra, S. 1997. Forced to Plough: Bonded Labour in Nepal's Agricultural Economy. Kathmandu: AntiSlavery International and INSEC.

Ruis, B.M.G.S. 2001. No Forest Convention but Ten Tree Treaties. Unasylva, 52(206): 113.

Springate-Baginski, O.; Soussan, J.; Dev, O.P.; Yadav, N.P. \& Kiff, E. 2000. Community Forestry Processes in Nepal: Progresses and Potentials. Kathmandu: Leeds University, UK and Nepal-UK Community Forestry Project.

Thoms, C.S.; Karmacharya, M.B. \& Karna, B.K. 2003. Exclusion Isn't Easy: Lessons from a Leasehold Forest. Forest and Livelihood, 2(2): 48-54.

UNDP. 2002. Nepal Human Development Report 2001: Poverty Reduction and Governance. Kathmandu: UNDP.

WFO. 2000. Nepal Food Security and Vulnerability Profile. Kathmandu: Nepal. 